\title{
The utilization of commercial media to engage and positively impact communities
}

\section{Werner, Thomas; Faerm, Steven}

Abstract:

Historically, corporations have targeted homogenous consumer groups through mainstream and social media. However, due to the radically shifting global marketplace and consumer demographics, corporations are developing heterogeneous visual narratives that fluidly cross cultural boundaries, engage the growing socially-minded consumer groups, and positively impact communities. Across organizational settings (e.g. for profit, non-for profit, and academia), these narratives are being disseminated to culturally diverse audiences to promote social change on a local, national, and/or international level. In this paper, the authors examine commercial imagery that creates

\section{Cuadernos del Centro de Estudios de Diseño y Comunicación N N 64}

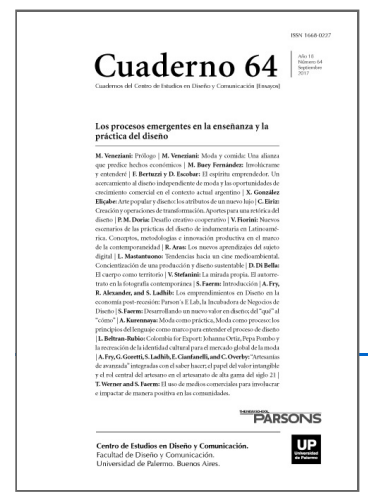

ISSN: 1668-0227

Los procesos

emergentes en la

enseñanza y la

práctica del diseño

Año XVIII, Septiembre 2017, Buenos Aires, Argentina | 326 páginas descargar PDF

ver índice de la publicación

Ver todos los libros de la publicación

compartir en Facebook

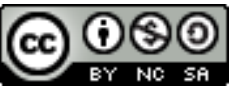

Esta obra está bajo una Licencia Creative Commons Atribución-NoComercialCompartirlgual 4.0 Internacional

compelling visual and written narratives to engender social and cultural change. Select campaigns developed by large corporations (e.g. Levis, Nike, Apple, and Dove) are presented to better understand cultural contexts, local/global consumer environments, and social impact. The authors then consider the function of these concepts as tools students may use to create successful visual narratives, and as illustrations of the challenges that may exist in a culturally diverse academic setting. Unique classroom settings are contextualized through four presentations on the topic, each in a culturally diverse setting. These settings include The United Nations Education First (UN/EF) Summer School; The State Hermitage Museum in Saint Petersburg, Russia; The Kaliningrad State Gallery, Russia; and Parsons School of Design, New York. The students' diverse perspectives provide insight into how visual and cultural language function in a commercial and educational context on a local, national, and international basis.

Key words:

Cultural - Cross-Cultural - Advertising Campaigns - Media - Commercial Media - Social Awareness 
(*) Assistant Professor and past Photography Program Director at Parsons School of Design in New York. Graduated of The University of Wisconsin with a Bachelors in Communications and an emphasis in film; The Art Center College of Design in Pasadena with a Bachelors in Photography and a film minor; and Long Island University with a Masters of Fine Art in New Media and Performance. He is the former owner of Thomas Werner Gallery in Manhattan's Chelsea Art District and currently a private art dealer, lecturing internationally on topics of photography, education, fashion and business.

**) Associate Professor of Fashion at Parsons School of Design (Program Director, BFA Fashion Design, 20072011). A Parsons alumnus (94') and Designer of the Year Nominee, he began teaching in 1998 while working for such designers as Marc Jacobs and Donna Karan. He has been recognized for his teaching by winning "The University Distinguished Teaching Award" and The BFA Fashion Design Program's "Teaching Excellence Award".

Introduction

Historically, corporations have targeted homogeneous consumer groups through mainstream and social media (Wedel \& Kamakura, 2002). However, due to the radically shifting global marketplace and consumer demographics, corporations are striving to develop visual narratives that move fluidly across cultural boundaries, engage the growing socially-minded consumer groups, and positively impact communities. Across organizational settings (e.g. for profit, non-for profit, and academia), these narratives are being disseminated to culturally diverse audiences across multiple media platforms to promote social change on a local, national, and/or international level. Commercial photography and video are rarely thought of as agents of social change. Yet commercial advertising campaigns increasingly address not only unique lifestyles, but also social concerns. Understanding how they do so presents the opportunity for students, educators, and socially engaged organizations to create compelling imagery that can affect cultural understanding and social change across cultural and geographic boundaries. These campaigns can reach millions of people across multiple media platforms. Select campaigns developed for Levis, Nike, Apple, and Dove, among others, will be examined in this paper to better understand cultural contexts, local/global consumer environments, social impact, and educational opportunities.

Personifying social change in commercial media

In 1997 Apple Computers launched the Think Different campaign, a series of advertisements in which it never showed their product. Instead, Apple presented a diverse group of ground breaking creative, cultural, social, athletic, and thought leaders that included Albert Einstein, Martha Graham, Pablo Picasso, the Dali Lama, Jackie Robinson, Mohammad Ali, Martin Luther King, and Nelson Mandela, among others. By incorporating these ground-breaking individuals who positively affected the world, the company conveyed the message that using an Apple computer was not simply about getting work done, but aligning yourself with some of the greatest scientific, political, artistic, spiritual, and innovative minds that humanity has produced. The inference was that you too could achieve greatness -with Apple products. This message is inspiring on an individual level, but it is the campaign's secondary message regarding societal diversity and acceptance that is truly empowering. Each of these individuals engaged with substantive social or cultural barriers and in doing so helped shape contemporary society. For instance, Jackie Robinson was the first black man to break the race barrier and play professional baseball; Martha Graham is the most influential female choreographer in the history of modern dance; Nelson Mandela fought apartheid and changed South Africa; and Martin Luther King fought for civil rights in America. 
Doctor King and the Dali Lama represent two very different approaches to religious change and peace. The inclusion of Albert Einstein and Muhammad Ali also speak to the acceptance of religious diversity across racial and cultural boundaries. As Apple's audience engaged with the commercial component of the campaign, they also engaged in a positive message of cultural, racial, religious, and creative freedom. This is the true strength of the Think Different campaign, as it is a rare example of a successful advertising campaign that delivers an intelligently articulated -albeit grammatically incorrect- multilayered social message that resonates across social, ethnic, and national barriers in a commercial context. The ability of advertising campaigns such as Think Different to deliver a multi-layered social message is powerful. Nike's Just Do It campaign has been doing so since 1988 with great success (Gianatasio, 2013). One advertisement from the Just Do It campaign depicts a woman in black sports pants and a form fitting red sport top photographed on a white background. In this image, she is dancing; her body and legs are in the air as she is supported by one arm on the ground beneath her. Her gaze is upward and she is pointing up into the air with her finger raised signaling the number one. The tag line "Just Do It" is positioned just beneath her. On first read, this image is about women's sports and dance. On the second read, it is about women's self-empowerment via the positive reinforcement of women's participation in sports. In this advertisement, the woman is looking upward toward the future; she is empowered and filled with hope, raising her hand and gesturing the number one as a symbol of possibility and social equality. A second image from the Just Do It campaign simply shows Nike's trademark "swoosh" with the tag line "Just Do It" underneath. Both the "swoosh" and tag line are filled with the colors of a brightly patterned rainbow. Both the "swoosh" and tag line are filled with a brightly patterned rainbow that alludes to the internationally recognized Lesbian, Gay, Bisexual, and Transgender (LGBT) community flag. This colorful logo is featured in Nike's collection of \#BETRUE apparel and advertising inspired by, and created in support of, the LGBT community.

\section{Controversy and provocation: campaigns that inspire social change}

Fashion advertisement campaigns are rarely considered agents of social change. Yet as an art form that speaks to our aspirations and desires, they provide powerful platforms for a number of companies for whom cultural awareness is part of their mission. The fashion brand Benetton has been a leader in the area of social issuebased advertising for decades. In the 1980s, Olivero Toscani, Benneton's in-house photographer and creative director from 1982 to 2000, produced the first of many multiracial campaigns under the "United Colors of Benetton" slogan (Armstrong, 2015). In later years, the Italian sportswear brand began to address more internationally controversial topics, including AIDS and Gulf War casualties (Mezzofiore, 2011). Benetton's strategy of using its symbolic photography to highlight the key social and political issues of the era made the brand synonymous with "shock advertising"; the fashion brand has created some of the most controversial advertising promotions in marketing history (Stevens, 1992). Benneton campaigns have included socially-minded images that prompt viewers to question race and racism. For one such campaign, three human hearts with the words "black", "white", and "yellow" superimposed over them remind viewers that despite differences in external skin color, we are all the same on the inside (Armstrong, 2015). In another advertisement, a photograph shows a young African albino girl surrounded by the non-albino members of her African tribe, calling us to question the definitions of race, tribe, and inclusion. Yet another advertisement depicts three children (one Black, one White, and one Asian), each playfully sticking their tongues out at the camera, reminding us of our innocence and ignorance of racial bias as children. In Benetton's world, there are no racial divides (Stevens, 1992). Benneton's socially-minded advertising campaigns continued well into the 2000s, and aimed to promote and advance international dialog around controversial topics. In 2003, the brand partnered with the United Nations World Food 
Program to create a campaign to address world hunger. All of the aforementioned photographs, which were included in this campaign, did more than shock: they sparked conversation, and, in doing so, challenged its predominantly upscale audience to question their preconceptions about race and globalization. Similarly, in 2011 the "Unhate" campaign was launched to promote tolerance and global love by displaying such images as Pope Benedict XVI kissing a top Egyptian imam (Butt, 2011). Controversy escalated and the advertisement was almost immediately withdrawn after the Vatican denounced it as an unacceptable provocation (Butt, 2011). Additional images from the campaign featured other national leaders kissing, including President Barack Obama and Venezuela's Hugo Chavez, and Israeli Prime Minister Benjamin Netanyahu and Palestinian President Mahmoud Abbas. In many of Benneton's campaigns the only adherence to conventional marketing was the presence of Benetton's green logo, as the social message was of primary importance (Stevens, 1992). The company's 2013 fashion campaign, which featured nine socially minded celebrities modeling clothes, was the first time Benetton moved away from more shocking imagery, placing a subtler social message in its campaign (Attwell, 2013). This change coincided with the arrival the new chairman of the company, Alessandro Benneton, who took over from his father Luciano Benneton (Armstrong, 2015). When asked whether the controversy around their social issue campaigns benefited the company, Alessandro replied:

I consider the controversial element as a very good side effect of what we're doing. It's part of the DNA of the brand to share views and vision about philosophical social issues. We've done it in the past and we'll do it in the future. Of the $500 \mathrm{~m}$ people who saw the 'kissing' campaign, more than $80 \%$, if I remember correctly, had a positive view of what we'd done. The fact that the Unhate Foundation supports good causes that link to the message of the campaigns, gives you a sense of the direction we're going in. (Attwell, 2013)

Benneton provides a compelling example of a campaign run through mainstream print media that confronts its audience and leads them to question their initial reactions, to look for answers, and perhaps to reconsider their perspective on the subject presented (Stevens, 1992). Issue-based campaigns do not need to be obvious or shock to engage their audience and effect change. Frequently, the subtlest imagery can have the greatest effect. Kenneth Cole has taken a different approach to producing socially progressive print campaigns, combining beautiful images of models wearing his clothes or accessories with tag lines that are at times a play on clothing and society, and other times a direct comment on western (generally American) social reality. Although the advertisements subtly address deep social concerns, they aim to heighten consumers' awareness in creative and unconventional ways. As Cole has stated, "Over the years we've sought to create a brand by taking risks and making statements that others hadn't and in ways that others wouldn't" (Karimzadeh, 2013). Advertisements with superimposed text such as, "We All Walk in Different Shoes", "If Gas Prices Continue to Rise, Why Not Switch Pumps", "In War Who Is Right and Who is Left", and "Think How Many Would Love to Be in Your Shoes" are direct plays on Cole's shoe line and social concerns. For example, the "We All Walk in Different Shoes" campaign in 2008 aimed to celebrate diversity by showing "real" people who live their lives in nonuniform ways, either through their own choice or circumstances. The campaign featured Paralympic athlete Aimee Mullins, an undocumented immigrant, a gay married couple and their daughter, HIV positive editor-in-chief of POZ Magazine Regan Hoffmann, and Channing Moss who was injured in the line of duty while serving in Afghanistan (Kenneth Cole Productions, Inc., 2008). Other more direct campaigns have included: "How You See the World Depends On How You Look", "Stand for Something or Stand Aside", "Wear Not War", "Is The Person Most at Risk the One with the Gun?", "What's Your View of You", "Make The Most of Wearing Times", and "Where Would We Be Without Our Rights". As conveyed in these campaigns, irony and double entendre are not solely the domain of 
the spoken or written word; they are tools that the maker of visual images uses as well in order to positively impact society. It is difficult to be subtle yet poignant; if a company or the not-for-profit sector can do so consistently, they will be able to build an audience and begin to affect social change.

Targeting consumers who can affect social change

A campaign's ability to affect change is not solely based on its content, but also its ability to target the audience an organization would like to inform, instruct, or persuade. Before creating a visual message, it is essential to research the target demographic to better understand where your target audience receives its information, whether that be television, print, radio, posters, word of mouth, or online media (Evans, 2013). For many young image makers, a campaign on YouTube, Vimeo, and other social media site is the first choice to reach a large audience due to lowest cost (Delzio, 2015). This option may engage large numbers of technologically connected individuals in a middle- or upper-income bracket, but may not reach people who have the power to affect the change you desire. Therefore, a campaign's goal cannot be to simply reach a broad swath of the general public, but to target those who influence a process socially or culturally. The general decision makers who can actually affect social change must be the campaign's focus. Selecting the appropriate media to successfully target a consumer who is able to affect social change is essential. Frequently, companies rely on the internet to target their consumers. However, in many countries, internet penetration and usage is generational and/or unreliable. For example, in the US, 96 percent of those between the ages of eighteen and twenty-nine use the internet, while just 58 percent age sixty-five and over use the technology (Statista, 2015a). In other parts of the world, internet connectivity, the lack of smart phones due economic challenges, or slow download speeds may make online video and social media less viable for reaching large consumer bases. For instance, in 2015 China had approximately 483.1 million internet users while Turkey had just 28.8 million users (Statista, 2015b). In some regions -particularly those with low internet access- newspapers are still the predominant form of information delivery, while in others it may be posters placed in populated areas or radio. However, these alternate forms of media can have significant benefits. For example, in Kenya, there has been a rapid expansion in the number and popularity of Ethnic FM Radio stations due to the liberalization of the airwaves and the relaxing of broadcasting monopolies by the state (Wekesa \& Tsuma, 2014). These radio stations produce local content in the local language, thus giving local communities a chance to contribute their views on the programs relevant to their needs (Wekesa \& Tsuma, 2014). The positive affect on program listeners can be high. Wekesa and Tsuma (2014) state:

Ethnic media insist on overt resistance to the commercialization of communication and the commodification of communities by refusing to treat them as passive anonymous 'audiences' or worse, mere targets for advertising. Instead, Ethnic media insists on the power and importance of the local and the micro issues that are relevant to audiences and participants on an everyday basis. (p. 252)

This local media fosters a sense of belonging for its community members; these members feel empowered and connected to a larger listenership, and this encourages a stronger sense of identity (Wekesa \& Tsuma, 2014). While local radio may empower a specific, targeted geographic community, other forms of commercial media target generational demographics that are aren't necessarily regionspecific. The 2009 Levi's Go Forth campaign took on a very different social narrative as it sought to redefine the brand for "Generation Z" and the millennial generation while also addressing its core audience, their parents. Launched during a global recession, the campaign's videos feature the work of American poet Walt Whitman whose poetry is inspirational in its discussion 
of youth, work, hope, and the possibilities of the future. The television commercial "O Pioneers!", part of the Go Forth campaign, includes overdubbing from Whitman's own narration of his poem "Pioneers! O Pioneers!" from his book Leaves of Grass (1855). This reading leverages the meter of the poem to establish the narrative structure for the piece. Simultaneously, the accompanying visuals are grounded in its cadence. Each scene is accompanied by Whitman's words urging the viewer onward: "We, the youthful sinewy races, all the rest on us depend, Pioneers! O pioneers!" Later he imparts, "Fresh and strong the world we seize, world of labor and the march, Pioneers! O pioneers!", and "Never must you be divided, in our ranks you move united, Pioneers! O pioneers!"(Whitman, 1855). The reading of the poem is supported by a slow guitar riff, with sharp claps of thunder and drum beats acting as auditory exclamation points. The overall soundtrack is so intentionally and intelligently integrated into the visuals and the concept of the piece that they are inextricably linked with one another. It is an extraordinary example of research and the re-contextualization of a historical performance and text in a contemporary space. Both the poem and its reading are relevant to the recessionary period in which the commercial was made, and to the multiple generations addressed by the campaign. The campaign ultimately brings a message of hope, rebuilding, rebirth, and the power of youth to its audience across multiple media platforms during the American 2009 recession. This message of hope, rebuilding, and rebirth developed by executive creative director Susan Hoffman is particularly salient when considering the recession-era context and the preceding failures of the traditional corporatized business landscape. Hoffman stated that the advertisements aim to pay homage to Levi's history, "but also to refresh and reinvent the idea of a pioneering spirit for the times in which we live" (Williams, 2009). These times:

"... are of course that of a recession and the spots feature a manifesto suggesting that one of the answers is to abandon suits and make a return to good ol' fashioned hard graft (presumably done while wearing Levi's jeans) -'I am the new American pioneer, looking forward, never back," it states. "No longer content to wait for better times... I will work for better times. Cause no one built this country in suits'”. (Williams, 2009, n.p.)

To question the stability of corporatized America is to return to the nation's core identity, thus enabled by the brand's product. Levi's continued to leverage American core identities in the brand's subsequent campaigns. In the We are all Workers campaign, both still and moving images work together to create its messaging. The still portion of the campaign, photographed by Melodie McDaniel, features "real" people in a town trying to recover (Elliot, 2010). In one scenario, the text "Everybody's Work is Equally Important" is superimposed over a photograph depicting a young black boy standing on a bed, intently buttoning his father's shirt in a simple bedroom. It communicates the bonding between father and son in the early morning before the father leaves for work. In a second piece from the campaign, we see a white father with his arms around his teenage son and daughter as they stand in front of a very simple working-class home. All three are dressed in slightly similar versions of work clothes and are looking directly at the camera with an understated style and a clear sense of strength and pride. The message in both of these images is simple: "Everybody's Work is Equally Important", whether it is a child's work, a father's work, or a family working together, whatever your age, race, or social standing. You, and the work that you do, matters. The moving image portion of the campaign opens with a man and his dog warming themselves by a fire in an open field. The scene then shifts to a lifeless industrial site, and on to an abandoned country home with the windows missing, followed by other images of loss and decay. This image is followed by a young boy jumping on his father who is asleep in bed, and a man in his 20's placing a bike in the back of his pick-up truck before driving off though the middle of a small deserted industrial town. The narrative suddenly shifts, showing young people getting ready to work, wearing hard hats and masks, with one 
punching the air like a boxer warming up for a fight. The soundtrack features an orchestral composition that begins slowly, gaining pace and volume throughout the commercial. Layered over this music we hear a boy's voice providing the narrative for the piece, a contemporary riff on Walt Whitman:

We were taught how the pioneers went into the West. They opened their eyes and made up what things could be. A long time ago, things got broken here. People got sad and left. Maybe the world breaks on purpose, so we can have work to do (Levi Strauss,2010).

The visuals begin to change and move through a series of vignettes showing young people installing stained glass into a barren building and weeding a garden. This scene brings the first dose of color to the commercial as hope begins to rise out of the ruins. The sun shines through a close up of the stained glass as the factory comes alive, and a father lifts his son into the air. The music builds in intensity as the camera follows a young black boy running toward a door at the end of a long, bare hallway. The camera switches to a first person perspective as it passes through the door rising into the sky, illustrating the possibilities that youth, hard work, and community may bring. We hear the music crescendo as the camera moves upward and the boy says, "People think there aren't frontiers anymore. They can't see how frontiers are all around us" (Levi Strauss, 2010). The tag line for the campaign then appears on the screen, "Go Forth", and then fades to black and the Levi's iconic logo. Shot with natural light and camera movement that intensifies in concert with the musical score, the campaign offers a message of hope for a better tomorrow. We are empowered, made the masters of our own destiny, "Everyone's Work is Equally Important", and together we can do anything. The video portion of the campaign appears it could have been shot on a smartphone as the image quality is not as crisp as most commercial productions, and its rapidly cut scenes are reflective of short video clips on Instagram. The Go Forth and We Are Workers campaigns ran in online and real life channels, including across multiple online media platforms with a focus on social media and as advertisements before movie previews in cinemas. Each clip utilized the visual language of the campaign's primary audience and/ or media platform. The offline, print version was placed in major fashion and lifestyle publications that focused on the company's primary and secondary audiences. These Levi's campaigns are excellent examples of demonstrating the importance of a company's understanding of its audience before it begins to work on creative concepts or a media plan. Furthermore, the We Are Workers campaign exemplifies how advertising can positively affect social change. A young single mother who recently became unemployed appeared in the campaign's advertisements and billboards, and the money she received proved highly beneficial (Elliott, 2011). The purpose of the campaign, stated by the campaign's co-creative director Tyler Whisnand, was "to show people who were really doing the work, the hard work, to rebuild after the recession", and it is serendipitous that "they need a good, sturdy pair of jeans or a trucker jacket to get down to work" (Elliott, 2011).

\section{Building emotional resonance for positive impact}

Dove, a consumer products and skin care company, took a different approach to reaching their audience. Over the past 12 years, Dove has run a series of Real Beauty advertising campaigns. The first campaign was launched in 2004 and featured non-professional models (or, "real women") of various ages and sizes whose appearance was outside the contemporary definition of beauty in the United States. The second campaign, launched in 2005, showed plus-size models and women with natural curves, with the goal of showing that thin is not the only form of beauty. In 2011, Dove released the findings of its largest global study to date on women's relationship to beauty -The Real Truth about Beauty: Revisited (2011). This study, which surveyed over 1,200 10to-17-year-olds, the majority of whom were female, revealed that only four percent of women around the world 
consider themselves beautiful; seventy-two percent of girls feel tremendous pressure to be beautiful; nine out of ten girls want to change at least one aspect of their physical appearance; and six out of ten girls are so concerned with the way they look that they are holding back from participating in important life activities (Dove, 2016 [2011]). Informed by these findings, Dove launched their third campaign, the 2013 online video campaign Real Sketches. In this campaign, individual women sat down with a police sketch artist and described themselves as the artist drew their portrait. When the sketch was completed the woman left the room and a second woman, a stranger who had a brief conversation with the first woman, sat down and also described the first woman to the sketch artist. In each case, the stranger described the initial sitter in a more traditionally positive and beautiful manner. The tag line at the end of the video read, "You Are More Beautiful than You Think". The point of the campaign was to communicate that women do not see themselves as realistically beautiful. According to Anselmo Ramos, currently executive creative director of Ogilvy \& Mather Brazil, and chief creative officer of the Real Beauty Sketches project, the goal of the Real Beauty Campaign was to find a way to convince the other ninety-six percent of women who don't believe they're beautiful to understand that they, too, are also beautiful (Grose, 2013). David Waterhouse, the global head of content and public relations at Unruly Media stated, "I think what made [the Real Beauty Sketches] campaign perform particularly strongly is the content, which elicited the intense emotional responses of 'warmth, 'happiness' and 'knowledge' from its target demographic — one of the key factors behind a video's sharing success" (Sampler, 2013). He continued, "But, more importantly, we are really seeing social motivations behind sharing becoming a lot more important. Brands have to give people a reason to share the video" (Stampler, 2013). The video created a sensation upon its online launch in April 2013, quickly going viral. More than 15 million people downloaded the video within a week of its release. Media reaction to the video was mixed. The Telegraph called it "[Dove's] most thought provoking film yet" (Young, 2013), while Forbes said it was "powerful" but that "it's still focusing too much on appearance" (Avi, 2013). This tradition of debate is something that Dove instills in all of its videos. Debate was at the core of the brand's most viewed campaigns, Real Beauty Sketches (141.9 million views) and Patches (58.3 million views) (Russell, 2014). Given the astounding number of views of the video and the strong viral response by its target audience, Real Sketches was named one of the top fifteen campaigns of the 21st Century by Advertising Age Magazine. George Hahn, Chief Compliance Officer of the BBDO Advertising Agency in New York, was one of the judges for the competition and called the campaign:

Bold, counter-intuitive work for this brand. Shows what can happen when a brand adopts a higher purpose. This could have been executed in a preachy-important way. Instead, they chose to lead you to their point, not simply tell you their point. (Neff, n.d.)

Other advertising campaigns addressing women's health issues have received similar positive support. The 2009 cross media campaign Circle of Life for Pink Ribbon Magazine, the annual magazine for the women's breast cancer charity Pink Ribbon, was developed to raise awareness for women's breast cancer. Created by Grey Adverting in The Netherlands for the greater European marketplace, the campaign consisted of an online prelaunch via blogs and social media followed by three print ads and a thirty-second television commercial. The agency's challenge was to break through the visual clutter of the highly competitive nonprofit sector to gain support from women, men, donors, and policy makers who had not already been directly affected by breast cancer. Grey Advertising placed a call for female volunteers who were willing take their shirts off for both the print and video portions of the campaign and 11,000 women responded. Women of all ages then had their topless torsos photographed. Three of the images were used in the print campaign and close to 100 still images made up 
the video portion of the project. In the television commercial, rapidly cut still images flash across the screen as a voiceover says:

Our story begins when our friends are quite small. But they grow up together in no time at all. They travel through life, having fun side-by-side, enjoying themselves, with nothing to hide. They share everything. No "ifs," "buts," or "maybes." Holidays, lovers, and eventually babies. They're so happy together every day, we like to keep it exactly that way. (Holgquist, 2010, p. 222)

This is followed by the tag line and call to action, "Support the battle against breast cancer". The three print pieces deliver a similar message as the video, with each consisting of a single photograph of a topless woman with a "celebratory and poignant poem [that] is written across the body, about the breasts. The breasts are seen as a pair of friends, with names, who should never be parted" (Wappling, 2013, n.p.). One image presents the text:

This is Eva and Faye; Who grow closer to each other, every day; They just hang around, without a clue; That one day they'll feed a baby or two. Eva is smaller, she won't disagree. With the right clothing, nobody will see. They share a life, do everything together, Let's hope that remains true forever. (Wappling, n.p., 2013)

The print and video versions of the campaign were easily translated from mass media to the online space, allowing Pink Ribbon to build upon the positive response to the mass media portion of the project. The Pink Ribbon Magazine campaign was a significant success; its friendly and heartwarming text and visual style helped it win a number of awards including Epica Gold, Epica Silver, LIA, SAN, Cannes Lions diploma, and being voted the public's favorite Dutch newspaper ad (van der Heuvel, 2009).

In the classroom: using commercial media to engage culturally diverse students

Each of the aforementioned campaigns were presented in culturally diverse classroom settings that included The United Nations Alliance of Civilizations -Education First (UN/EF) summer school; The State Hermitage Museum in Saint Petersburg, Russia; The Kaliningrad State Gallery, Russia; and Parsons School of Design, New York. The students' diverse perspectives provide insight into how visual and cultural language function in a commercial and educational context on a local, national, and international basis. When conducing small group discussions, workshops, and broader student debates, the students' reactions to the commercial media campaigns evidenced highly differentiated interpretations that were often shaped by their unique cultural backgrounds. The United Nations Education First Summer School and The New School University are particularly unique educational settings due to their large international student cohorts. The New School has the largest percentage of international students of any major university in America (US News Report, n.d.). The United Nations Education First Summer School has hosted between seventy-two and one-hundred students from seventy-two to ninetyfour different countries, with the cohort chosen from over 14,000 applications worldwide (UNAOC-EF, n.d.). Students' responses to each of the campaigns varied from location to location. This not only speaks to the varying reaction to visual narratives cross-culturally, but also unexpected cultural interpretations that may arise in a diverse classroom setting. Offering a space in which students felt safe and understood they would not be judged for their opinion facilitated student response, and opened the door to a deeper "dive" into the campaigns and the issues they addressed. Apple's Think Different campaign found the most universal acceptance across all six educational locations. Its positive message of individual empowerment and use of imagery that subtly addresses social 
issues were well received. Students focused on the extraordinary cultural accomplishments of each individual and less on race, gender, religion, or politics. In general, students found one or more individuals or occupations that they could relate to in the campaigns, and this form of self-identification opened the door to the opportunity for personal growth and broader classroom dialog. As Angela Celebre and Ashley Waggoner Denton (2014) note in their article, The Good, the Bad, and the Ugly of the Dove Campaign for Real Beauty, the notion of perceived similarity was in effect. Perceived similarity, within the context of social comparison theory, suggests that those who are considered similar are assimilated to the self. The lack of a visceral response to any of the images or text in the campaign allowed for the engagement of a diverse range of issues without pushback. Students in each of the educational contexts embraced the idea of individual or societal aspiration, and success. Understanding this response gives educators a device with which they may raise important social issues with a greater opportunity for a positive response. During the first two United Nations Education First Summer Schools, The Kaliningrad State Gallery, and the State Hermitage Museum, discussions of the Nike Just Do It campaign created highly different responses between the male and female cohorts. The campaign -which addressed women's rights and the idea of self-empowerment for women by depicting a girl dancing and raising her hand to signal the number one- created a slightly uncomfortable response from the young men and a more vocal, positive response from women. Girls who reside in patriarchal societies where women may openly participate in sports or dance had the strongest positive response to the ideas of self-empowerment and success in sports. Those from countries in which their participation in sports is either not promoted or not accepted showed a less vocal response to this advertisement, while still supporting the idea of women's equality. In these instances, sport, too, was a mediator for the introduction of conversations around social justice. However, when confronted with more direct imagery around the same topic of self-empowerment in the Nike campaign -such as the Nike's rainbow "swoosh" that suggested lesbian, gay, bisexual, and transgender rights- students' negative responses were slightly more pronounced when compared to Apple's Think Different campaign. In contrast, the reaction to the same advertisement of the girl dancing by students at The New School was one of acceptance; the advertisement did not rise to the level of provocation. It is important to note that all of these classrooms provided a safe environment where diverse opinions were not only encouraged but respected. The second image from the Just Do It campaign -which shows Nike's trademark "swoosh" filled with the colors of a brightly patterned rainbow and the tag line "Just Do It" underneath- drew a much stronger response in Russia, a country where the dispersal of gay propaganda to minors is against the law. When the image was presented during a lecture at the State Hermitage Museum in Saint Petersburg, Russia, one of the authors asked the audience what they believed the advertisement was about. One girl's immediate response was that given the rainbow, the advertisement spoke to LGBT rights, and the support and empowerment of this group. Another girl quickly responded that this interpretation was over reaching and that Nike had no intention of promoting or supporting LGBT rights. The conversation within the room was impassioned on both sides of the issue. Nike has not stated the intention of this advertisement, but its ability to activate a deep cultural dialog within a community in which this conversation is frequently limited speaks to the power of advertisement. Benneton's images proved to be more provocative for discussion and garnered a more vocal positive or negative response from students at all of the institutions. Images promoting peace and acceptance -such as the black and white hand forming a heart, a diverse group of three young children laughing, or 3 identical human hearts with the words, "black", "white", and "yellow"- were positively received by many students. An image of five different colored condoms laid out in the form of the Olympic rings brought smiles in every classroom setting. However, when the secondary concepts of birth control, sexually transmitted diseases, and death were introduced in conjunction with this particular image, the conversation became subdued, but nobody had a negative response to these secondary messages. The 
photograph of a young albino girl surrounded by the black members of her African tribe evoked the most interesting responses, as students across the institutions were at first silent, and then some began to question their notions of race and tribe. The conversation in every setting was calm and measured, and one of acceptance as opposed to exclusion. Levi's Oh Pioneers and We Are Workers campaigns received the most positive response across students at these internationally diverse institutions. Although the images in the two campaigns did not directly represent many of the cultures of the students in the classrooms, they did speak to the concepts of youth, hope, and empowerment that cut across cultural boundaries. Equally important were the manners in which the campaigns were photographed, with the feel of an Instagram picture or video. By utilizing the visual language of the current younger generation, Levi's was able to engage the students and make them believe that the future -and the power to change it- is theirs. Notably, there was an interesting response to the We Are Workers campaign that surfaced at both the UN/ EF Summer School and at the Hermitage. A number of students said that the campaign gave them a different perspective on the United States, as they could not imagine it having cities in decay, the importance of work ethic and family, or the ability of youth to effect social change. In most instances these concepts ran counter to the perception of the United States in their country, and the manner in which it is portrayed in the media. The Dove Real Sketches beauty campaign created a strong response at the UN/EF Summer School and at The New School. Girls at the both institutions adamantly questioned the company's definition of beauty, arguing that the manner in which the women originally portrayed themselves was itself beautiful. They also questioned what they felt was an American/European-centric perspective on beauty, and were concerned that notions of beauty from other cultures were excluded. Finally, they felt too much importance was being placed on the idea of being beautiful, as the video did not speak to the importance of intelligence. Interestingly, the young men did not take part in this dialog, though it is difficult to know if that was due to a disconnect to the message of the campaign or the force of the young women's argument. Additionally, girls at The New School questioned whether it was ethical for a corporation to promote a social issue-centered advertising campaign that was, in essence, making a profit from women's perceived insecurities. All of the students agreed on the need for corporations to be socially engaged, but could not agree on the best methodology in an advertising environment.

The Pink Ribbon Beauty campaign received the most unexpected response at the UN/ EF Summer School. After the still images and video had been screened, some of the girls voiced their discomfort with the nudity and questioned whether the same message could have been made without showing women's breasts. The fact that women's health issues were being addressed was viewed positively by young women of all backgrounds, but particularly by those from countries where women do not enjoy the same rights as men. The cultural differences between the countries represented by the students was the most evident during this dialog as there were cultural, moral, and religious undertones to the conversation. After this campaign was shown and discussed, students broke into groups of ten to discuss their upcoming project; projects were to be informed by the methodologies employed in the aforementioned advertising campaigns. When one the authors visited a group in the back of the room, one young man turned to him and said, "You could be killed in my country for showing those [nude] pictures". The author told him that he understood, but the UN/EF school aimed to foster an open environment where diverse ideas could be safely discussed. Moreover, the author noted the campaign was about women's health issues and the nudity was not meant in a sexual manner, but as a way to connect with women who may not be checking themselves. At that moment, the students in the group were silent. His friend turned to the author and said, "You do not understand, they would kill you. Dead". This was a reprimand for violating these young men's social code; the implied threat informed this author that he should not continue to press the issue in this 
classroom situation, though women's healthcare issues and the right to be self-empowered are important in every culture. As a teacher, utilizing the Pink Ribbon Campaign as an educational tool would not be the appropriate choice in more conservative socio-cultural contexts. It was at this point that the young women began to defend a women's right to healthcare, and the conversation shifted in that topic's direction. Although the students' commentary and veiled threat were unexpected, the outcome was an open, public dialog where young people supported one another as they asked for equality in a safe environment. Students at The Hermitage Museum and The New School were comfortable with the visual content in the Pink Ribbon Beauty campaign, though the introduction of this conversation into the public sphere was uncomfortable for many of the Russian girls as this was deemed a private topic, and is not one readily discussed between men and women.

\section{Conclusion}

Radically shifting methods of targeting and distribution, combined with evolving consumer demographics on local, national, and international levels, are changing the manners in which for- and non-profit entities create and disseminate their advertising campaigns' messages. Campaigns increasingly center around visual narratives that are able to cross cultural boundaries, engage a growing socially-minded generation, and aim to affect positive social change; this social change can occur at the local, national, and/ or international levels. Organizations strategically disseminate their messages by using appropriate forms of media that target a specific audience and environment; the success of these advertising campaigns, then, is no longer restricted to their content, but to their abilities to target the audience the organization would like to inform, instruct, or persuade. These abilities are particularly meaningful and impactful when the campaigns successfully target audience members who can actually affect change. The cultural shifts witnessed in commercial media campaigns are also displayed in tertiary education. Many universities and schools are experiencing increased quantities of cultural diversity due to immigration and an increasing number of students studying abroad. This increasingly diverse classroom setting contains students whose experiences and beliefs are highly specific to their own local -and at times, marginalized-cultures. How students experience the world and (in the case of this study) commercial media, has been framed through their own cultural "lenses" that may be contrarian to their international peers' norms. Thus, utilizing commercial media as a learning tool to promote dialog around global social issues (e.g. human rights) can lead to profound positive impact; these conversations can erode negative biases, prejudices, and barriers, and promote understanding and acceptance. Educators working within increasingly diverse academic settings cannot assume their students possess a singular cultural perspective or a shared understanding regarding the imagery brought into the classroom and disseminated into the world. It is essential that educators and students become aware of, and respect, the diverse social and cultural histories with which all engage in the global environment.

\section{References}

Armstrong, A. (2015, October 24). Benetton leaves shock tactics behind as it seeks to stay in fashion. The Telegraph. Retrieved from http://www.telegraph.co.uk/finance/newsbysector/ retailandconsumer/11952130/Benetton-leaves-shock-tactics-behind-as-it-seeks-to-stayin-fashion.html Attwell, J. (2013, February 14). Alessandro Benetton on building a brand out of controversy. Marketing Magazine Online. Retrieved from http://www.marketingmagazine.co.uk/ article/1170425/alessandro-benetton-building-brandcontroversy Avi, D. (2013, April 21). Dove's new video is a beauty, but is it a bit skin deep? Forbes. Retrieved from http://www.forbes.com/sites/avidan/2013/04/21/doves-new-video-is-abeauty-but-is-it-a-bit-skin- 
deep/\#417f1db248c5 Butt, R. (2011, November 17). Benetton tears down pope-kissing ads after Vatican legal threat. The Guardian. Retrieved from http://www.theguardian.com/world/2011/nov/17/ benetton-pope-kissing-ads Celebre, A. \& Denton, A. (2014, February). The good, the bad, and the ugly of the Dove campaign for real beauty. The Inquisitive Mind Magazine. Retrieved from http://www.inmind.org/article/the-good-the-bad-and-theugly-of-the-dove-campaign-for-real-beauty Delzio, S. (2015, June 9). 12 social media marketing trends for small business. Social Media Examiner. Retrieved from http://www.socialmediaexaminer.com/social-mediamarketingtrends-for-small-business/

Dove, Inc. (2016 [2011]). Our research. Retrieved from http://www.dove.us/Our-Mission/ Girls-Self-Esteem/OurResearch/default.aspx Elliott, S. (2010, June 23). Levi's features a town trying to recover. The New York Times. Retrieved from http://www.nytimes.com/2010/06/24/business/media/24adco.html. Evans, M. (2013, March 20). The importance of really knowing your target audience. Forbes. Retrieve from http://www.forbes.com/sites/markevans/2013/03/20/the-importance-ofreally-knowing-your-targetaudiences/\#415f04966ddc Gianatasio, D. (2013, July 2). Happy 25th birthday to Nike's 'Just Do It,' the last great advertising slogan. Advertising Week. Retrieved from http://www.adweek.com/adfreak/ happy-25th-birthdaynikes-just-do-it-last-great-advertising-slogan-150947 Grose, J. (2013, April 19). The story behind Dove's mega viral "Real Beauty Sketches" campaign. Co.Create. Retrieved from http://www.fastcocreate.com/1682823/thestorybehind-doves-mega-viral-real-beauty-sketches-campaign Hogquist, R. (2010). Epica book 23: Europe's best advertising. London: Thames \& Hudson, Ltd. Karimzadeh, M. (2013, January 27). Kenneth Cole marks 30 years with ad campaigns. Women's Wear Daily. Retrieved from http://wwd.com/globe-news/advertising/kennethcolemarks-30-years-6663843/ Kenneth Cole Productions, Inc. (2008). We all walk in different shoes: 25 Years of nonuniform thinking. PR Newswire. Retrieved from http://www.prnewswire.com/newsreleases/we-all-walk-indifferent-shoes-56807927.html Levi Strauss \& Co. (2015). We are all workers: 2010 Levis Strauss \& Co. commercial [Television Commercial]. Retrieved from http://adsoftheworld.com/media/tv/levis_to_work Mezzofiore, G. (2011, November 18). Benetton: A history of shocking ad campaigns. International Business Times. Retrieved from http://www.ibtimes.co.uk/benetton-historyshocking-ad-campaigns-pictures-252087 Neff, J. (n.d.). What the judges had to say about Dove's 'campaign for real beauty.' Advertising Age. Retrieved from http://adage.com/lp/top15/\#realbeauty Russell, M. (2014, June 9). How Dove's campaign for real beauty ushered in new age of female empowerment. Visible Measures. Retrieved from http://www.visiblemeasures. com/2014/07/09/how-doves-campaign-for-real-beauty-ushered-in-new-age-of-femaleempowerment/ Stampler, L. (2013, May 22). How Dove's 'Real Beauty Sketches' became the most viral video ad of all time. Business Insider. Retrieved from http://www.businessinsider.com/ how-doves-real-beauty-sketches-became-the-most-viral-advideo-of-all-time-2013-5 Statista. (2015a). Share of internet users in the United States as of May 2015, by age group. Retrieved from http://www.statista.com/statistics/266587/percentage-of-internet-usersby-age-groups-inthe-us/ Statista. (2015b). Number of internet users in selected countries as of May 2015 (in millions). Retrieved from http://www.statista.com/statistics/271411/number-of-internet-users-inselected-countries/ Stevens, M. (1992, December 11) Change the world, buy a sweater. Chicago Tribune. Retrieve from http://www.chicagoreader.com/chicago/change-the-world-buy-a-sweater/ Content?oid=880996

\section{U.S. News Report (n.d.) Most international students: National universities. Retrieved from}

http://colleges.usnews.rankingsandreviews.com/best-colleges/rankings/nationaluniversities/most-international United Nations Alliance of Civilizations - Education First (UNAOC-EF). (n.d.). Overview. Retrieved from http://www.unaocefsummerschool.org/ Wappling, D. (2013). Pink Ribbon Magazine launched - poetry for our girls 
(Boobies!). Adland. Retrieved from https://adland.tv/ooh/pink-ribbon-magazine-launched-poetryour-girls-boobies. Wedel, M. \& Kamakura, W.A. (2002). Introduction to the special issue on market segmentation. International Journal of Research in Marketing, 19, 181-183. Wekesa, A. S. \& Tsuma, F. C. (2014). Ethnic Media and Rural Development in Kenya. International Journal of Humanities and Social Science, 2(1), 246-253. Williams, E. (2009, June 30). Levi's Go Forth. Creative Review. Retrieved from https://www. creativereview.co.uk/crblog/2009/june/levis-go-forth/ Whitman, W., Cowley, M., \& Charles E. Feinberg Collection of Walt Whitman (Library of Congress). (1959). Walt Whitman's Leaves of grass: The first (1855) edition. New York: Viking Press. Young, K. (2013, April 22). Dove's new beauty campaign confirms that we are more beautiful than we think. The Telegraph. Retrieved from http://fashion.telegraph.co.uk/ beauty/news-features/TMG10009657/Doves-newbeauty-campaign-confirms-that-weare-more-beautiful-than-we-think.html

\section{Resumen:}

Históricamente, las empresas se han dirigido a grupos de consumidores homogéneos a través de los diferentes medios de comunicación social. Sin embargo, debido a los cambios radicales de los mercados y de los consumidores, las empresas están desarrollando narrativas visuales heterogéneas que atraviesan de manera fluida las fronteras culturales, involucran a los crecientes grupos de consumidores socialmente comprometidos, y producen un impacto positivo en las comunidades. Estas narraciones se difunden al público de diversas culturas para promover el cambio social a nivel local, nacional y / o internacional. En este trabajo, los autores examinan las imágenes comerciales que crean narrativas visuales y escritas de peso para generar cambios sociales y culturales. Se presentan las campa- ñas desarrolladas por grandes empresas como Levis, Nike, Apple y Dove, para una mejor comprensión de los contextos culturales, entornos de consumo local / global, y el impacto social. Luego, los autores consideran la función de estos conceptos como herramientas que los estudiantes pueden utilizar para crear narrativas visuales exitosas, y como ejemplos de los desafíos que pueden existir en un entorno académico culturalmente diverso. Una única configuración áulica se contextualiza a través de cuatro presentaciones sobre el tema, cada uno en un entorno culturalmente diverso: la Escuela de Verano de The United Nations Education First (UN/EF); el Museo Estatal del Hermitage en San Petersburgo, Rusia; la Galería Estatal de Kaliningrado, Rusia; y Parsons School of Design, New York. Las distintas perspectivas de los estudiantes permite entender cómo se percibe la función del lenguaje visual y cultural en un contexto comercial y educativo a nivel local, nacional e internacional.

Palabras clave:

Cultural - intercultural - Campañas publicitarias - medios - medios comerciales - conciencia social.

\section{Resumo:}

Históricamente, as empresas se dirigiram a grupos de consumidores homogê- neos através dos diferentes meios de comunicação social. Contudo, devido às mudanças radicais dos mercados e dos consumidores, as empresas estão desenvolvendo narrativas visuais heterogêneas que atravessam fluidamente as fronteiras culturais, envolvem aos crescentes grupos de consumidores socialmente comprometidos, e produzem um impacto positivo nas comunidades. Estas narrações se difundem ao público de diversas culturas para promover a mudança social a nível local, nacional e/ou internacional. Neste trabalho, os autores examinam as imagens comerciais que criam narrativas visuais e escritas de peso para gerar mudanças sociais e culturais. Apresentam- 
se as campanhas desenvolvidas por grandes empresas como Levis, Nike, Apple e Dove, para uma melhor compreensão dos contextos culturais, ambientes de consumo local/global e o impacto social. Depois, os autores consideram a função destes conceitos como ferramentas que os estudantes podem utilizar para criar narrativas visuais bem sucedidas, e como exemplo dos desafios que podem existir num ambiente acadêmico culturalmente diverso. Uma única configura- ção áulica se contextualiza através de quatro apresentações sobre o tema, cada um num ambiente culturalmente diverso: a Escola de Verão de The United Nations Education First (UN/EF); o Museu Estadual do Hermitage em San Petersburgo, Rusia; a Galeria Estadual de Kaliningrado, Rusia; e Parsons School of Design, Nova York. As diferentes perspectivas dos estudantes permitem compreender como se percebe a função da linguagem visual e cultural num contexto comercial e educativo a nível local, nacional e internacional.

Palavras chave:

cultural - inter-cultural - campanhas publicitárias - meios - meios comerciais - consciência social.

The utilization of commercial media to engage and positively impact communities fue publicado de la página 277 a página294 en Cuadernos del Centro de Estudios de Diseño y Comunicación № 64 